\title{
Defending Disclosure in Software Licensing
}

\author{
Robert A. Hillman $\dagger \&$ Maureen O'Rourke $\dagger$
}

This Article surveys prominent kinds of disclosures in contract law-of facts, contract terms, and performance intentions. We show why the disclosure tool, although subject to substantial criticism, promotes important social values and goals, including efficiency, autonomy, corrective justice, fairness, and the legitimacy of the contract process. Further, proposals to replace disclosure with other alternatives are unrealistic because they are too expensive or complex. Our working example is the American Law Institute's Principles of the Law of Software Contracts.

\section{INTRODUCTION}

For lack of our imagination, this Article does not have the most scintillating title. The subject matter, however, is critically important. We survey prominent kinds of disclosures in law and show why the disclosure tool, though subject to substantial criticism, is central to the legitimacy of any legal regime. Our working example is the American Law Institute's Principles of the Law of Software Contracts' ("ALI Principles").

The ALI Principles include three kinds of disclosure: disclosure of facts (concerning the quality of software), disclosure of terms (of standard forms), and disclosure of postcontract intentions (to pursue remote disablement of software). We take up each respectively in the three Parts that follow and show how these forms of disclosure promote important social values and goals.

\section{DISCLOSING FACTS}

Section 3.05(b) of the ALI Principles provides that a party that transfers software (by sale, license, or otherwise) and receives money or a monetary obligation warrants "that the software contains no material hidden defects of which the transferor was aware at the time of

$\dagger$ Edward H. Woodruff Professor of Law, Cornell Law School.

†† Dean, Professor of Law, and Michaels Faculty Research Scholar, Boston University School of Law.

The authors thank George Hay, Stewart Schwab, and the faculties of Boston University School of Law and Cornell Law School for their comments. Daniel Forester provided excellent research assistance.

1 ALI, Principles of the Law: Software Contracts (2010) ("ALI Principles"). We disclose that we are the Reporters for this project. 
the transfer." This section does no more than incorporate existing contract law's duty to disclose and tort's fraudulent concealment law. Still, the section has concerned some software licensors largely on the false ground that the section creates new licensee rights. ${ }^{4}$ In addition, some licensors claim that the section will increase litigation, a tired cry often heard by those opposing laws that protect parties from overreaching. Here, we show that this longstanding disclosure rule makes sense on any of a number of normative and policy grounds.

2 ALI Principles $\S 3.05$ (b) at 193 (cited in note 1). The Principles apply to software contracts, including those denominated licenses, sales, or access contracts. ALI Principles $\S 1.06$ at 19 (cited in note 1 ). But $\$ 3.05$ (b) does not apply if the transferor does not receive money or a right to payment of a monetary obligation; hence, it excludes many open-source transfers. Section 3.05(b) states in full:

A transferor that receives money or a right to payment of a monetary obligation in exchange for the software warrants to any party in the normal chain of distribution that the software contains no material hidden defects of which the transferor was aware at the time of the transfer. This warranty may not be excluded. In addition, this warranty does not displace an action for misrepresentation or its remedies.

3 ALI Principles \$3.05, Reporters' Notes to comment b at 197-200 (cited in note 1), provides in part:

Under the common law, a contracting party must disclose material facts if they are under the party's control and the other party cannot reasonably be expected to learn the facts. Failure to disclose in such circumstances may amount to a representation that the fact does not exist and may be fraudulent. See, e.g., Hill v. Jones, 725 P.2d 1115, 1118-1119 (Ariz. Ct. App. 1986) ("[U]nder certain circumstances there may be a 'duty to speak.'... [N]ondisclosure of a fact known to one party may be equivalent to the assertion that the fact does not exist. ... Thus, nondisclosure may be equated with and given the same legal effect as fraud and misrepresentation."). The Restatement Second of Contracts $\S 161(b)$ supports the Hill dictum: "A person's non-disclosure of a fact known to him is equivalent to an assertion that the fact does not exist ... where he knows that disclosure of the fact would correct a mistake of the other party as to a basic assumption on which that party is making the contract and if non-disclosure of the fact amounts to a failure to act in good faith and in accordance with reasonable standards of fair dealing." Section 161, Comment $d$, of the Restatement Second adds: "In many situations, if one party knows that the other is mistaken as to a basic assumption, he is expected to disclose the fact that would correct the mistake. A seller of real or personal property is, for example, ordinarily expected to disclose a known latent defect of quality or title that is of such a character as would probably prevent the buyer from buying at the contract price."

The Restatement (Second) of Contracts $\$ 161$ (1981) applies the law of fraudulent concealment, which requires knowingly suppressing facts that the other party reasonably cannot ascertain with the intent of misleading that other party to her detriment. See Gibb v Citicorp Mortgage, Inc, 518 NW2d 910, 916 (Neb 1994).

4 See, for example, Letter from Karen Copenhaver, Counsel for the Linux Foundation and Horacio Gutierrez, Corporate Vice President and Deputy General Counsel, Microsoft Corporation, to Professor Robert A. Hillman, Cornell Law School, et al *1 (May 14, 2009), online at http://www.chineselinuxuniversity.net/news/55619.shtml (visited Oct 28,2010 ) (expressing concern that adoption of the ALI Principles "could lead to disruption of the well-functioning software market, increased uncertainty for software developers, and increased litigation risk").

5 See, for example, Karen F. Copenhaver and Mark F. Radcliffe, American Law Institute Principles of the Law of Software Contracts Letter, 954 PLI/Pat 159, 164 (2008). 


\section{A. Economic Efficiency}

As a general matter, the efficiency standard calls for "the adoption of legal rules that facilitate the movement of assets to their most productive uses with as few transaction costs as possible." A duty to disclose material defects contributes to this goal in several ways. For example, the duty increases the flow of information and therefore the likelihood that each party will value what it gets more than what it gives up. ' In addition, a disclosure duty allocates the risk of material defects to the party best able to accommodate or avoid them. As a comment to $\S 3.05$ (b) states: "Hidden material defects, known to the software [licensor] but not disclosed, shift costs to the [licensee] who cannot learn of the defects until it is too late and therefore cannot protect itself." ${ }^{\prime 8}$ A disclosure duty should also create incentives for the software licensor to improve the quality of its software.'

Disclosure also reduces transaction costs. For example, $\$ 3.05(\mathrm{~b})$ applies only if the licensee cannot reasonably ascertain the material defect. $^{10}$ Therefore, a licensee need not engage in a costly and ultimately useless investigation to uncover material defects, information already in the possession of the licensor."

6 Michael J. Trebilcock, The Limits of Freedom of Contract 112 (Harvard 1993).

7 See Alan Strudler, Moral Complexity in the Law of Nondisclosure, 45 UCLA L Rev 337, 349-50 (1997) ("[T] he more information individuals possess about goods they buy and sell, the more reason society has to think that these goods will go to those who most value them, and hence, the better off society will be.").

8 ALI Principles $\$ 3.05$ (b), comment b at 194 (cited in note 1). The line between misrepresentation and concealment is not bright. See, for example, Michael J. Borden, Mistake and Disclosure in a Model of Two-Sided Informational Inputs, 73 Mo L Rev 667, 671 (2008) (emphasizing that silence has a "communicative or signaling effect[]"). See also Richard Craswell, Taking Information Seriously: Misrepresentation and Nondisclosure in Contract Law and Elsewhere, 92 Va L Rev 565, 566 (2006).

9 See Craswell, 92 Va L Rev at 587-88 (cited in note 8) ("In regulatory settings, agencies are often concerned with improving buyers' information precisely in order to give sellers better incentives to improve the quality of their offerings.").

10 Under $\$ 3.05(\mathrm{~b})$, the licensor must disclose only hidden defects, which means that "the defect[s] would not surface upon any testing that was or should have been performed by the [licensee]." ALI Principles $\S 3.05$, comment b at 194 (cited in note 1).

11 Professor Michael Trebilcock asserts that "there should be a general presumption in favour of disclosure of material facts known to one party and unknown to the other." Otherwise, people will "invest in wasteful precautions to generate information about the asset" that the first party already has. Trebilcock, Limits of Freedom of Contract at 112 (cited in note 6). See also Richard A. Posner, Economic Analysis of Law 112 (Aspen 7th ed 2007) ("[C]osts are avoided by the imposition on the seller of a duty to disclose information that he obtained costlessly."); Melvin A. Eisenberg, Disclosure in Contract Law, 91 Cal L Rev 1645, 1647 (2003); Marc Ramsay, The Buyer/Seller Asymmetry: Corrective Justice and Material Non-disclosure, 56 U Toronto L J 115, 130 (2006). 
But does the duty to disclose material defects create other costs that outweigh the benefits of the rule ${ }^{12}$ One prominent issue in the literature of disclosure law is the effect of disclosure on the incentives to "generate and utilize [] information in the first place." ${ }^{\text {" Professor }}$ Anthony Kronman argues that the law does not require disclosure of deliberately acquired information in order to create an incentive to acquire the information. For example, a company might not search for oil if it had to disclose its findings to a prospective seller of the land, who obviously would raise the price if he knew of the oil. Requiring the disclosure of casually acquired information, on the other hand, does not discourage the production of information. ${ }^{14}$

Analysts are almost unanimous in concluding that disclosure of important information by sellers is desirable notwithstanding Kronman's analysis. ${ }^{15}$ For example, Professor Michael Trebilcock urges that sellers must disclose adverse information because nondisclosure would "substantially impair the expected value of the transaction to the buyer," whereas the adverse information is a "sunk cost" for the seller. ${ }^{16}$ The role of the law is to deter "further misallocat[ion]" of the resources. ${ }^{17}$ In addition, sellers would likely acquire information about their assets even if required to disclose the information. ${ }^{18}$ This certainly is likely in the case of software licensors, who inevitably uncover problems with their software in the process of engineering, debugging, and manufacturing it. ${ }^{19}$

An additional potential cost of disclosure identified in the literature is that it would require wasteful disclosures of either unimportant

12 See Craswell, 92 Va L Rev at 566-67 (cited in note 8) ("In deciding whether any given disclosure is desirable, both benefits and costs must be considered.").

13 Trebilcock, Limits of Freedom of Contract at 112 (cited in note 6). In a twist, Professor Steven Shavell worries about excessive investment in information. He points out that "[w]here information has low social value, its costly acquisition should be discouraged, suggesting the desirability of requiring its disclosure." Steven Shavell, Foundations of Economic Analysis of Law 334 (Harvard 2004).

14 See Anthony T. Kronman, Mistake, Disclosure, Information, and the Law of Contracts, 7 J Legal Stud 1, 15-16 (1978). Alan Strudler remarks that Kronman's analysis is "calamitously speculative." Strudler, 45 UCLA L Rev at 361 (cited in note 7).

15 See, for example, Shavell, Foundations of Economic Analysis of Law at 333 (cited in note 13) ("The appeal of requiring disclosure is stronger when sellers possess information than when buyers do, for the simple reason that it is buyers who typically can make socially valuable use of information."); Eisenberg, 91 Cal L Rev at 1676 (cited in note 11).

16 Trebilcock, Limits of Freedom of Contract at 114 (cited in note 6).

17 Id.

18 Trebilcock writes that a seller's product information is "casually acquired in the sense that enforced disclosure is unlikely to diminish significantly [ ] investment." Id at 113. See also id at 112; Eisenberg, 91 Cal L Rev at 1676 (cited in note 11).

19 A software licensor might argue that debugging is itself an investment, but it is an investment that licensors likely make to ensure the profitability of their software. 
information or information the buyer already knows. ${ }^{20}$ In such situations, the costs of disclosing minor information likely exceed the benefits to the party receiving the information. Further, if that party already has the information, the costs of disclosure are "redundant." But $\$ 3.05(b)$ does not apply to defects the licensee knows about or to immaterial defects. Another related problem with disclosure is that it might "obscur[e] other, more important information." 22 But there is hardly more important information than that the software contains defects that render it substantially useless.

Those opposed to the material defect disclosure rule focus on still another possible cost of disclosure, namely its administrative costs. For example, is the rule clear enough to deflect unwarranted claims? Does the rule create unmanageable proof issues? ${ }^{23}$ Does the rule create unduly costly notification requirements? We submit that the administrative costs of $\S 3.05$ (b) should be quite manageable mainly because the rule borrows from longstanding existing law that clarifies issues, including the law of material breach and reasonable expectations. A comment to the section elaborates on the operation and boundaries of the rule:

Section 3.05(b) requires that the [licensor] know of the defect at the time of the transfer, the defect is material, and it is hidden. The time of the transfer is the time of conveyance of rights in the software or of authorization to access software. ...

A material defect consists of a software error serious enough to constitute a material breach of the contract. ... [T] established common-law material-breach doctrine, which ask[s] whether the injured party received substantially what it bargained for and reasonably expected, inform[s] the court's decision on whether a defect is material. Software that requires major workarounds to achieve contract-promised functionality and that

20 See, for example, Trebilcock, Limits of Freedom of Contract at 107, 112 (cited in note 6). See also Posner, Economic Analysis of Law at 113 (cited in note 11) ("The case for requiring disclosure is strongest when a product characteristic is not ascertainable by the consumer at low cost.").

21 Posner, Economic Analysis of Law at 113 (cited in note 11).

22 Craswell, 92 Va L Rev at 566 (cited in note 8).

23 Trebilcock worries about such costs, but recognizes that "administrative costs cannot be absolutely determinative of contract rules or we would simply ban all actions for breach of contract." Trebilcock, Limits of Freedom of Contract at 115 (cited in note 6).

Failure to disclose can be a real problem in the world of technology. The New York Times reported in June 2010 that Dell sold millions of computers "riddled with faulty electrical components that were leaking chemicals and causing [] malfunctions" for two years and that documents revealed that the company's employees "were actually aware that the computers were likely to break." Ashlee Vance, Suit over Faulty Computers Highlights Dell's Decline, NY Times B1 (June 29, 2010). 
causes long periods of downtime or never achieves promised functionality ordinarily would constitute a material defect.

Disclosure of a material hidden defect occurs when a reasonable [licensee] would understand the existence and basic nature of the defect. Disclosure ordinarily should involve a direct communication to the [licensee], if feasible. A mere posting of defects on the [licensor's] website may be insufficient depending on the circumstances. ...

Putting together the requirements of [a licensor's] actual knowledge of the defect at the time of the transfer, [a licensee's] reasonable lack of knowledge, and a defect that constitutes a material breach means that a [licensor] would not be liable if the [licensor] has received reports of problems but reasonably has not had time to investigate them, if the [licensee's] problems are caused by uses of which the [licensor] is unaware, if the [licensor] learns of problems only after the transfer, or if the problems are benign or require reasonable workarounds to achieve functionality. ${ }^{24}$

Finally, opponents are troubled because the disclosure rule is mandatory. Case law, however, supports the proposition that a party cannot contract away responsibility for fraud. ${ }^{25}$ In addition, the argument in favor of mandatory disclosure is heightened in the case of standard form contracts where the licensee typically is not even aware of disclaimers. ${ }^{26}$ Even in negotiated deals, a reasonable licensee would believe that an "as is" clause or the like insulates a licensor from liability for defects that are known or unknown by both parties at the time of contracting, not those known and knowable by only the licensor that render the software substantially worthless. For such reasons, the law should not aid and abet fraud.

Mandatory disclosure of material defects in market software serves still another purpose. Disclosure means potential access by other software users to information about the quality of a licensor's software. Sharing such information is consistent with the spirit of the growing software commons movement. ${ }^{27}$

24 ALI Principles $\S 3.05$, comment b at 194-95 (cited in note 1).

25 Disclaimers and "as is" clauses often do not preclude claims of fraud. See, for example, Limoge v People's Trust Co, 719 A2d 888, 891 (Vt 1998); Gibb, 518 NW2d at 918. But see Trebilcock, Limits of Freedom of Contract at 114 (cited in note 6) (explaining that a seller can "contract out of" his duty to disclose by "stipulating ... that he is selling goods 'as is'").

26 See notes 46-64 and accompanying text.

27 See Robert A. Hillman and Maureen A. O'Rourke, Rethinking Consideration in the Electronic Age, 61 Hastings L J 311, 313 (2009). 
For the reasons discussed, we are confident that the benefits of $\S 3.05$ (b) outweigh its costs. Those less certain, however, might argue that nonlegal sanctions are sufficient to produce optimal disclosure. For example, licensors do not want to injure their reputations by distributing close-to-worthless software. But licensors may be able to hide behind software's tendency to contain bugs and avoid the loss of many customers despite licensing software they know to be dysfunctional. ${ }^{28}$ Further, fly-by-night software licensors that can "exit the market at low cost" and large licensors that enjoy a quasi-monopoly position would be less motivated by reputational concerns. ${ }^{29}$ Finally, licensors who infrequently market software with known hidden defects may believe that the damage to their reputations from nondisclosure of those defects will be minimal. ${ }^{30}$

A frequent additional argument of those who oppose consumer protection is that sellers will simply raise prices. ${ }^{31}$ Software licensors adopting this argument with respect to $\S 3.05(\mathrm{~b})$ would be in the unusual position of having to claim that they will raise prices if they are not permitted to conceal material facts fraudulently. Further, we have already shown that the disclosure rule's lines are bright and that licensors have little to fear from spurious litigation..$^{32}$ If we are correct, then we can expect prices to be fair because they should correspond to the actual value of the licensed software.

\section{B. Additional Normative Grounds}

Several additional theories and principles support or explain the material-defect disclosure rule. For example, under the principle of autonomy, a licensee's agreement is not voluntary if the licensee does not have the material facts. ${ }^{33}$ Closely related, corrective justice requires a legal system that has "respect and concern for people who are duped." ${ }^{34}$ In the context of software licensing, the law therefore should

28 See Posner, Economic Analysis of Law at 113 (cited in note 11) (theorizing that competitors are unlikely to disclose defects that their products share).

29 Id at 112-13.

30 See Alon Harel and Yuval Procaccia, On the Optimal Regulation of Unread Contracts *4 (unpublished manuscript, Sept 2009), online at http://ssrn.com/abstract=1473770 (visited Oct 28, 2010) (reasoning that with "low-probability contingencies ... potential transmitters of ... information will be small, and hence reputation will perform poorly as a vehicle for market correction").

31 See, for example, Craswell, $92 \mathrm{Va} \mathrm{L} \mathrm{Rev} \mathrm{at} 618$ (cited in note 8) (discussing this argument).

32 See notes 23-24 and accompanying text.

33 See Trebilcock, Limits of Freedom of Contract at 107 (cited in note 6).

34 Strudler, 45 UCLA L Rev at 349 (cited in note 7). 
seek to ensure that the licensee makes knowledgeable decisions about her assets. ${ }^{35}$

Contractarians posit that "individuals behind a veil of ignorance but aware of their cultural and social context" would assent to rules that protect a party from catastrophe..$^{36}$ Accordingly, a party must disclose "deep secrets," meaning that the other party reasonably has no knowledge of the information." A party should also disclose "shallow secrets," in which the other party has an inkling of the secret, if the first party received the information because of its "special advantage. ${ }^{38}$ In the context of software disclosure, contractarians would therefore argue that the licensor must disclose material hidden defects if the licensee reasonably is unaware that the software is defective. Even if the licensee has some knowledge of a problem but is reasonably unaware of the specifics, contractarians would urge a disclosure duty.

Moralists would require disclosure as a matter of right and wrong. ${ }^{39}$ For example, moralists argue that it is "impermissible to take advantage of another party's ignorance of material facts. ${ }^{, 40}$ Further, "[u]sing [ ] ignorance to increase one's own profits violates respect for persons.."11 Failure to disclose known material defects in software also constitutes bad faith under this interpretation. ${ }^{42}$

Finally, prospect theory helps explain the apparent asymmetry between the disclosure requirement of sellers and buyers (here licensors and licensees), with only the former subject to an aggressive

35 See Ramsay, 56 U Toronto L J at 124-25 (cited in note 11). See also id at 143 ("[T]he buyer cannot ... sell [disclosed] information to other prospective buyers. Since other buyers are themselves protected by the disclosure rule, they too would receive this information free of charge during the bargaining process with the seller in question.").

36 Trebilcock, Limits of Freedom of Contract at 109 (cited in note 6), discussing Kim Lane Scheppele, Legal Secrets: Equality and Efficiency in the Common Law 57-86 (Chicago 1988) (examining the way in which Anglo-American legal culture discusses and regulates secrets).

37 Trebilcock, Limits of Freedom of Contract at 109 (cited in note 6) (“'[D]eep secrets' [exist] where the target of the secret has no reason for imagining the existence of the information in question."). See also Ramsay, $56 \mathrm{U}$ Toronto L J at 126 (cited in note 11).

38 Craswell, 92 Va L Rev at 571 (cited in note 8). See also Trebilcock, Limits of Freedom of Contract at 109 (cited in note 6) (explaining that "shallow" secrets consist of "relevant information" that the target of the secret "has reason to suspect the existence of").

39 See Robert A. Hillman, The Richness of Contract Law: An Analysis and Critique of Contemporary Theories of Contract Law 12-19 (Kluwer 1997), discussing Charles Fried, Contract as Promise: A Theory of Contractual Obligation 17 (Harvard 1981) ("[S]ince a contract is first of all a promise, the contract must be kept because a promise must be kept.").

40 Ramsay, $56 \mathrm{U}$ Toronto $\mathrm{L} \mathrm{J}$ at 134-38 (cited in note 11), discussing Fried, Contract as Promise at 78-83 (cited in note 39) (presenting a corrective theory of fraud).

41 Ramsay, $56 \mathrm{U}$ Toronto L J at 135 (cited in note 11), discussing Fried, Contract as Promise at 78-83 (cited in note 39 ).

42 See, for example, Hillman, Richness of Contract Law at 152-56 (cited in note 39). 
requirement at common law..$^{43}$ Prospect theory observes that people suffer from a loss of assets more than they feel good about a comparable gain in assets. ${ }^{44}$ Consistent with the theory, the law requires sellers to disclose material information about goods because the buyer loses (is made worse off) if the buyer purchases worthless goods. On the other hand, if a buyer fails to disclose material facts, then the seller foregoes a gain. "Seller does not exactly lose anything ... by selling without Buyer's information. [Seller] sells at a price equal to or above the market price. [Seller] is merely deprived of the benefit created by Buyer's investment." ${ }^{, 45}$ The law of disclosure simply may reflect this cognitive bias.

Disclosure about the facts relating to the quality of software is not the only kind of disclosure in the ALI Principles. We now turn to the issue of disclosure of standard terms.

\section{DISCLOSING TERMS}

A well-accepted proposition is that, for a host of reasons, people do not read their standard forms. ${ }^{46}$ Further, electronic commerce may have exacerbated the problem. ${ }^{47}$ These realities create a dilemma for contract law in the electronic age. For example, they undermine contract law's paradigm of assent by knowledgeable parties. ${ }^{48}$ They also increase the likelihood that some licensors will draft terms that overreach. ${ }^{49}$ What

43 Thanks to Professor Jeffrey Rachlinski for this insight. Ramsay analyzes the asymmetry, but does not focus on prospect theory. See Ramsay, $56 \mathrm{U}$ Toronto L J at 123-32 (cited in note 11). For a discussion of this psychological theory as it applies to disclosure, see Eisenberg, $91 \mathrm{Cal}$ L Rev at 1675-76 (cited in note 11) ("[N]ondisclosure by a seller usually results in a loss to the buyer, since the commodity is worth significantly less than he pays for it. Because a loss is felt more sharply than a forgone gain, there is extra reason to be solicitous about protecting buyers against nondisclosure sellers.").

44 See Eisenberg, 91 Cal L Rev at 1675 (cited in note 11).

45 Borden, 73 Mo L Rev at 700 (cited in note 8) (arguing that a seller who is duped "has no conventional expectation of ... surplus").

46 See Robert A. Hillman and Jeffrey J. Rachlinski, Standard-Form Contracting in the Electronic Age, 77 NYU L Rev 429, 436 (2002) ("The consumer, engaging in a rough but reasonable cost-benefit analysis of these factors, understands that the costs of reading, interpreting, and comparing standard terms outweigh any benefits of doing so and therefore chooses not to read the form carefully or even at all."); Robert A. Hillman, Online Consumer Standard Form Contracting Practices: A Survey and Discussion of Legal Implications, in Jane K. Winn, ed, Consumer Protection in the Age of the "Information Economy" 283, 283-94 (Ashgate 2006).

47 See Hillman and Rachlinski, 77 NYU L Rev at 468 (cited in note 46).

48 Id at $482-83$.

49 See Craswell, 92 Va L Rev at 591 (cited in note 8):

[I]f consumers have perfect information about the prices offered by different sellers, and perfect information about the average effects of contract terms in sellers' standard forms, but if they have no information (or only poor information) about the effect of the contract terms used by any individual seller, each seller will then have an incentive to degrade the "quality" of its terms. 
should contract law, and in this instance, the ALI Principles, do about this problem? One of us has written extensively on this subject, and we will not repeat many of the arguments here. ${ }^{\text {so }}$ Instead, we simply set forth and then defend the ALI Principles' disclosure-of-terms strategy against concerns of some analysts.

The ALI Principles do not require a precontract disclosure of terms. ${ }^{51}$ Instead, the Principles set forth a safe harbor that ensures enforcement of standard forms so long as they are not unconscionable or against public policy. ${ }^{52}$ The safe harbor requires software licensors, among other things, to make their forms available on the Internet prior to any transaction so that a prospective customer can shop around for terms if so inclined. ${ }^{53}$ Admittedly, few people likely will do so, which is the principal basis for complaints about the disclosure strategy, although we believe that the situation may not be as hopeless as some allege. ${ }^{54}$ Nevertheless, here we rest the justification for a disclosure safe

50 See, for example, Hillman and Rachlinski, 77 NYU L Rev at 486-95 (cited in note 46); Hillman, Online Consumer Standard Form Contracting Practices at 295-300 (cited in note 46).

51 Section 2.02(b) of the ALI Principles adopts the common law's objective test of assent. ALI Principles $\$ 2.02$ (b) at 121 (cited in note 1). Section 2.02(c) simply sets forth a strategy to ensure satisfaction of the objective test. ALI Principles $\$ 2.02$ (c) at 121 (cited in note 1). Some who have concerns about the ALI approach do not always make this clear. See, for example, Florencia Marotta-Wurgler, Will Increased Disclosure Help? Evaluating the Recommendations of the ALI's "Principles of the Law of Software Contracts," 78 U Chi L Rev 165, 184 (2011) ("[I]ncreased disclosure alone cannot be counted upon to make a difference, and it is dangerous to believe otherwise."). See also id at 172 ("Increased disclosure regimes have been broadly criticized for being ineffective.").

52 Nor is the disclosure safe harbor the ALI Principles' sole approach to standard forms. See, for example, ALI Principles $\S 2.03$ (d) at 144 (cited in note 1) (modification); ALI Principles $\S 4.03$ (c) at 263 (cited in note 1) (automated disablement).

53 See $A L I$ Principles $\$ 2.02$ (c) at 121 (cited in note 1) ("A [licensee] will be deemed to have adopted a standard form as a contract if [] the standard form is reasonably accessible electronically prior to initiation of the transfer at issue ...."). The safe harbor also requires a "clickwrap" acceptance of terms, which means that the "I accept" icon must appear at the end of, or adjacent to, the standard form. See ALI Principles \$2.02(c)(3) at 121 (cited in note 1). But see Robert A. Hillman and Ibrahim Barakat, Warranties and Disclaimers in the Electronic Age, 11 Yale J L \& Tech 1, 5 (2009) (revealing that thirty-four out of one hundred of Amazon's bestselling software titles did not disclose their terms).

54 For detailed criticism of disclosure in this context, see Omri Ben-Shahar, The Myth of the "Opportunity to Read" in Contract Law, 5 Eur Rev Cont L 1, 5 (2009) ("[E]ven with a "robust' opportunity to review the information about the contract terms, very few individuals will jump on this opportunity and actually read."). Notwithstanding Professor Omri Ben-Shahar's criticism of disclosure, we believe that increasing access to standard forms on the Internet reduces some of the roadblocks to reading, such as time constraints and search costs. Nevertheless, in the following discussion we assume that people will not read their standard forms for all of the reasons discussed in Professor Ben-Shahar's provocative article. But we confess to some confusion over whether Professor Ben-Shahar sees any value in disclosure. We think that he does. For example, he is comfortable with the terms-after-payment process only if "there is an option not to take the contract as a whole." Id at 11-12. Apparently, terms-after-payment is satisfactory to Professor Ben-Shahar because the purchaser can exercise the option to reject the contract after having the opportunity to read the terms. See also Marotta-Wurgler, $78 \mathrm{U}$ Chi L Rev at 167-68 (cited in 
harbor on other grounds. In addition, we argue that the cost of disclosure is negligible. Finally, we assert that alternative proposals either are unrealistic and expensive or can easily supplement the disclosure rule.

The opportunity to read a standard form is important in part because it substantiates assent to the form even if a party does not read it. The ALI Principles reason that

[i]ncreasing the opportunity to read supports autonomy reasons for enforcing software standard forms and substantiates Karl Llewellyn's conception of [licensees'] "blanket assent" to reasonable standard terms, so long as they have had a reasonable opportunity to read them. Blanket assent means that [licensees] have delegated to the drafter the duty of drafting reasonable boilerplate terms, just as they delegate to software [licensors] and engineers the duty of creating the appropriate software for the task at hand. ${ }^{5 s}$

Llewellyn's "blanket asset" approach is more than an abstraction. It describes the reality of what is in the minds of reasonable people who agree to standard forms. But there is more. A fundamental tenet of the rule of law is reasonable notice. For example, in criminal law, "fair warning" requires that the law "explicit[ly] [] inform those who are subject to [the law] what conduct on their part will render them liable to its penalties." ${ }^{56}$ The goal is to "give the person of ordinary intelligence a reasonable opportunity to know what is prohibited." Yet we all know that people rarely read criminal statutes or understand many of the intricacies of rules governing even those wrongs of which they are aware, such as murder or theft. The point is that people could gain access to these materials, which legitimizes the rules as

note 51) (concluding from empirical evidence that "contract accessibility does not result in an economically significant increase in readership" and suggesting that the promotion of "increased disclosure would be ineffective and could even introduce new costs and inefficiencies").

55 ALI Principles at 118 (cited in note 1).

56 Keeler v Superior Court, 470 P2d 617, 626 (Cal 1970), quoting Connally v General Construction Co, 269 US 385, 391 (1926) (describing fair notice as "[t]he first essential of due process"). See also Paul H. Robinson, Fair Notice and Fair Adjudication: Two Kinds of Legality, 154 U Pa L Rev 335, 336 (2005) ("[T]he legality principle ... means that criminal liability and punishment can be based only upon a prior legislative enactment of a prohibition that is expressed with adequate precision and clarity."); Douglas N. Husak and Craig A. Callender, Wilful Ignorance, Knowledge, and the "Equal Culpability" Thesis: A Study of the Deeper Significance of the Principle of Legality, 1994 Wis L Rev 29, 30.

57 Robinson, $154 \mathrm{U}$ Pa L Rev at 360 (cited in note 56), quoting Grayned $v$ City of Rockford, 408 US 104, 108 (1972). See also McBoyle v United States, 283 US 25, 27 (1931) ("Although it is not likely that a criminal will carefully consider the text of the law before he murders or steals, it is reasonable that a fair warning should be given to the world in language that the common world will understand, of what the law intends to do if a certain line is passed."). 
law. ${ }^{58}$ Further, the importance of the common law principle of stare decisis does not depend on the proposition that people actually know and understand precedent, but on the notion that the legal texts are available to them. ${ }^{59}$ That is why courts take great pains to legitimize decisions that stray from precedent by distinguishing the cases on the facts even in situations where it is clear that the parties did not have an inkling of that precedent.

Standard forms constitute private legislation backed by the state's enforcement processes, and the legitimacy of these forms also depends on reasonable notice of content. In fact, adequate notice of terms constitutes a foundation for much of contract doctrine, including rules of interpretation (such as interpreting terms against the drafter), the parol evidence rule, and, of course, the general rules of formation. To be sure, creating a safe harbor that requires greater access to standard forms is a modest contribution if the goal is to increase reading. But it is a crucial step if the goal is to create legitimacy in the contracting process. ${ }^{60}$

Increasing the opportunity to read also may lead to the improvement of the quality of standard forms. As we have said, we doubt that disclosure will increase the numbers of readers substantially. Nor do we subscribe to the argument that a few readers create sufficient incentives for licensors to improve the quality of terms. ${ }^{61}$ But watchdog groups have already sprung up on the Internet, and the digital revolution means that information they collect about "dangerous

58 Thanks to Professor Sherry Colb for this observation. See Note, Textualism as Fair Notice, 123 Harv L Rev 542, 543, 546-48 (2009) ("From the inception of Western culture, fair notice has been recognized as an essential element of the rule of law."); id (arguing that fair notice "promotes social efficiency by allowing people to order their behavior within an established legal framework").

59 See, for example, Planned Parenthood v Casey, 505 US 833, 869 (1992) (explaining that overruling precedent would come at "the cost of both profound and unnecessary damage to the Court's legitimacy, and to the Nation's commitment to the rule of law"); Payne v Tennessee, 501 US 808, 827 (1991) ("Stare decisis ... contributes to the actual and perceived integrity of the judicial process.") (second emphasis added).

60 Florencia Marotta-Wurgler refers to such benefits as "relatively intangible," as if this means they can be ignored. Marotta-Wurgler, $78 \mathrm{U}$ Chi L Rev at 183 (cited in note 51).

61 See, for example, Alan Schwartz and Louis L. Wilde, Intervening in Markets on the Basis of Imperfect Information: A Legal and Economic Analysis, 127 U Pa L Rev 630, 638 (1979) ("[I]f enough searchers exist, firms have incentives both to compete for their business and to offer the same terms to nonsearchers. When the preferences of searchers are positively correlated with the preferences of nonsearchers, competition among firms for searchers should tend to protect all consumers.”). But see generally Yannis Bakos, Florencia Marotta-Wurgler, and David R. Trossen, Does Anyone Read the Fine Print? Testing a Law and Economics Approach to Standard Form Contracts (NYU Center for Law, Economics and Organization Working Paper No 09-40, Oct 2009), online at http://ssrn.com/abstract=1443256 (visited Nov 3, 2010). 
terms" can easily be disseminated. ${ }^{62}$ Licensors therefore have reason to be concerned about the nature of terms that are easily accessible, as Facebook recently learned when it introduced a term that appropriated its users' information. ${ }^{63}$ Protests fueled in part by Internet communications caused Facebook to retract this infamous term. ${ }^{64}$

Disclosure is also inexpensive and, at worst, harmless. The ALI Principles point out that " $[\mathrm{t}]$ he costs of maintaining a web homepage and displaying a standard form should be insignificant, especially because virtually all software [licensors] have or soon will have a web page." ${ }^{65}$ Further, proving that a licensor complied with the obligation should not be difficult:

Many [licensors] already maintain archival records of website content, including when material was introduced, modified, and removed. Server logs also indicate when and if a web page was modified. . . . Helpful corroborative evidence would include, for example, the testimony of visitors to the [licensor's] website at or near the time of the contested transaction. [Licensors] can locate these visitors through their web logs. In the longer term, improvements in technology and entrepreneurial activity will create new methods of proving website content over time. For example, entrepreneurs are already establishing independent archiving services that can lend credibility to a [licensor's] proof of web content. ${ }^{66}$

A potential cost of disclosure that one of us has described in detail previously is that disclosure will increase the possibility that marginal terms will be enforceable, because disclosure eliminates the argument that such terms are procedurally unconscionable. ${ }^{67}$ Many businesses do not make their standard forms available prior to a transaction, however,

62 See Ben-Shahar, 5 Eur Rev Cont L at 24 (cited in note 54) (discussing EULAlyzer, "a free downloadable software that analyzes the boilerplate terms of other software"); Annalee Newitz, Dangerous Terms: A User's Guide to EULAs (Feb 2005), online at http://www.eff.org/wp/dangerousterms-users-guide-eulas (visited Oct 28, 2010). But see Ronald J. Mann and Travis Siebeneicher, Just One Click: The Reality of Internet Retail Contracting, 108 Colum L Rev 984, 987 (2008) (reporting relatively fair terms in large retailers' Internet standard forms).

63 See Chris Walters, Facebook's New Terms of Service: "We Can Do Anything We Want with Your Content. Forever.," Consumerist (Feb 15, 2009), online at http://consumerist.com/5150175/ facebooks-new-terms-of-service-we-can-do-anything-we-want-with-your-content-forever (visited Oct 28, 2010).

64 See Brad Stone and Brian Stelter, Facebook Withdraws Changes in Data Use, NY Times B1 (Feb 19, 2009) ("After three days of pressure from angry users and the threat of a formal legal complaint by a coalition of consumer advocacy groups, the company reversed changes to its contract with users that had appeared to give it perpetual ownership of their contributions to the service.").

65 ALI Principles $\$ 2.02$, comment $\mathrm{f}$ at 132 (cited in note 1 ).

66 ALI Principles $\$ 2.02$, comment $\mathrm{g}$ at $132-33$ (cited in note 1 ).

67 Robert A. Hillman, Online Boilerplate: Would Mandatory Website Disclosure of E-standard Terms Backfire?, 104 Mich L Rev 837, 853 (2006). 
suggesting that they believe that the costs of disclosure outweigh the benefit of creating a litigation defense. ${ }^{6}$ Perhaps these secretive businesses worry about the long term, believing that eventually word will get out about their marginal terms. If this prediction is accurate, then disclosure ultimately will benefit software end users notwithstanding a possible drop in successful unconscionability cases. ${ }^{69}$

Finally, alternative proposals either are unrealistic because they are too expensive or unwieldy or could easily supplement the disclosure safe harbor. ${ }^{70}$ For example, one proposal, discussed and rejected in the ALI Principles, is to enforce terms only if a licensee clicks "I agree" at the end of each term-or at least the particularly contentious ones, such as forum selection and dispute resolution terms. ${ }^{71} \mathrm{Nei}-$ ther licensors nor licensees desire the contract formation process to become bogged down in such formalities, which ultimately may not promote any additional reading anyway. ${ }^{72}$

An additional proposal is to create a government agency to provide oversight or even preapproval of the content of standard forms. ${ }^{73}$ This strikes us as costly and subject to the common pitfalls of administrative rulemaking, including agency capture by the software industry, lack of

68 See, for example, Hillman and Barakat, 11 Yale J L \& Tech at 5 (cited in note 53).

69 See Hillman, 104 Mich L Rev at 856 (cited in note 67), quoting Daylian M. Cain, George Loewenstein, and Don A. Moore, The Dirt on Coming Clean: Perverse Effects of Disclosing Conflicts of Interest, 34 J Legal Stud 1, 3 n 2 (2005), quoting Action on Smoking and Health, Warning: History of Tobacco Manipulation of Congress: Tobacco Deal Has Potential for Even Greater Dirty Tricks (Sept 11, 1997), online at http://web.archive.org/web/20000819050841/ no-smoking.org/sept97/9-11-97-1.html (visited Feb 20, 2010):

Consider the experience of cigarette manufacturers who, in response to legislation, put warning labels on their packages. For a considerable period of time, these labels helped manufacturers "fend] off smokers' suits" based on smokers' assumption of the risk. As a result, "[w] hat was intended as a burden on tobacco became a shield instead." In the long run, however, the package warnings, along with the many revelations about cigarette manufacturers' attempts to hide other adverse facts about their products, led to a massive change in public opinion and, ultimately, to serious legal sanctions against the cigarette companies. Perhaps mandatory website disclosure will also have a long-term beneficial effect.

70 See Marotta-Wurgler, 78 U Chi L Rev at 185 (cited in note 51) (arguing that alternativeto-disclosure solutions "would be costly to implement and should not be formally proposed by the authorities without evidence that these costs are outweighed by benefits").

71 ALI Principles at 120 (cited in note 1).

72 Hillman and Barakat, 11 Yale J L \& Tech at 26 (cited in note S3) ("[E]xtra clicking would be cumbersome for little gain because consumers would simply click without digesting the disclaimer.").

73 See Clayton P. Gillette, Preapproved Boilerplate, in Omri Ben-Shahar, ed, Boilerplate: The Foundation of Market Contracts 95, 97-102 (Cambridge 2007). The European Union has created a nonexclusive list of contractual terms that may be considered unfair when not individually negotiated. See Council Directive 93/13/EEC of 5 April 1993 on Unfair Terms in Consumer Contracts, 1993 OJ L95/29 (Apr 21, 1993). The ALI Principles "opt to rely on traditional unconscionability doctrine rather than defining which terms are enforceable and which are not. A court may, however, find the Directive's list useful in evaluating unconscionability claims." ALI Principles $\S 1.11$, comment c at 78-79 (cited in note 1). 
agency resources, and inattention to context-dependent variables. In addition, as a matter of principle, agency involvement is troublesome because it increases government intrusion into what should remain an essentially private process. ${ }^{74}$

Another proposal is for the private sector to rate contracts, just as rating services presently evaluate restaurants and hotels, among other things. ${ }^{75}$ Of course, the disclosure rule discussed here does not contradict or impede such a strategy. In fact, we have already discussed the importance of watchdog groups and would applaud their employment of a systematic rating service, if indeed the quality of terms can be so rated. ${ }^{76}$ But, of course, for such ratings to succeed, the first step would be to make standard forms easily accessible, which is precisely what the ALI Principles seek.

A final strategy worth mentioning, in the case of terms-afterpayment, is to identify and label important provisions on packaged software." Disclosure of terms on the Internet does not impede this reform either. In fact, the ALI Principles admonish software providers to disclose terms on the package. ${ }^{78} \mathrm{~A}$ challenge will be selecting the terms that must appear on the package without repeating most of the contract there.

We now discuss a third kind of disclosure, namely disclosure of ex post remedial strategies.

\section{Disclosing Ex Post STRATEGIES}

Contract law permits a wide variety of postbreach conduct, sometimes requiring disclosure in the agreement of postbreach intentions as a condition of enforcement, sometimes not. ${ }^{79}$ Here, we focus on a

74 See Robert A. Hillman, Contract Law in Context: The Case of Software Contracts, 45 Wake Forest L Rev 669, 680 (2010).

75 See Ben-Shahar, 5 Eur Rev Cont $L$ at 22-25 (cited in note 54).

76 See notes 62-64 and accompanying text.

77 In rolling contracts, people "see the terms after paying for goods." Robert A. Hillman, Rolling Contracts, 71 Fordham L Rev 743, 743 (2002). See also Ben-Shahar, 5 Eur Rev Cont $L$ at 26 (cited in note 54) ("Labeling of standard form contract terms can be designed ... [with] a uniform box in a uniform and prominent place on the package.").

78 ALI Principles $\$ 2.02$, comment b at 126 (cited in note 1) (providing that, "[i]f the [licensee] can read the standard form before opening the software because, for example, the standard form is printed on or attached to the package," the licensee may be bound to the form).

79 Consider, for example, UCC Article 2's remedial scheme. The parties may opt to rely on the UCC's default rules, which, by their mere existence as background law, give notice of the parties' intentions on breach. For example, in the case of a defective tender by the seller, the buyer may reject the goods or accept them and sue for damages. UCC $\$ \$ 2-601,2-714$. A rejection is "ineffective unless the buyer seasonably notifies the seller." UCC \$ 2-602(1). The seller, in turn, may have a right to cure under certain circumstances, with exercise of that right dependent on the seller's "seasonably notify[ing]" the buyer. UCC $\$ 2-508$. 
particular type of postbreach conduct in business settings - the nonbreaching licensor's automated disablement of software resident on the breaching party's computer. ${ }^{80}$ The Principles place several restrictions on such disablement, including that the term authorizing it must be in the agreement and be conspicuous. ${ }^{81}$

Automated disablement of software is essentially a high-tech version of self-help. Historically, contract law-most notably the UCC in the context of secured transactions - has not required disclosure in the agreement of an intent to use self-help. ${ }^{82}$ Rather, the nonbreaching party may simply rely on the background law to exercise self-help in the event of breach. Why do we depart from that approach here?

As we noted earlier in the context of a duty to disclose material defects, disclosure can increase the flow of information and therefore the likelihood that each party will value what it receives more than what it gives up. ${ }^{83}$ Although self-help has a long history under UCC

Parties often contract around the default remedies, however, by setting liquidated damages or limiting remedies. Such liquidation or limitation generally must be a part of the agreement itself, thus effectively requiring disclosure of postbreach strategy. UCC \& 2-718(1) ("Damages for breach by either party may be liquidated in the agreement."); UCC \$2-719(1)(a) ("[T]he agreement may provide for remedies in addition to or in substitution for those provided in this Article.").

80 See ALI Principles $\$ 4.03$ (a) at 263 (cited in note 1) ("Automated disablement' means the use of electronic means to disable or materially impair the functionality of software."). See also ALI Principles $\$ 4.03($ a), comment a at 264 (cited in note 1) ("The Section applies ... in both the remedial and other contexts."). In this Article, we concentrate on electronic disablement as a remedy for breach.

The Principles do not permit automated disablement in a consumer agreement or in a standard-form transfer of generally available software. ALI Principles $\$ 4.03$ (c) at 263 (cited in note 1). The Principles define "consumer agreement" as "an agreement for the transfer of software or access to software primarily for personal, family, or household purposes." ALI Principles $\$ 1.01(\mathrm{~d})$ at 7 (cited in note 1). They define "standard-form transfer of generally available software" as "a transfer using a standard form of (1) a small number of copies of software to an end user; or (2) the right to access software to a small number of end users," provided that "the software is generally available to the public under substantially the same standard terms." $A L I$ Principles $\$ 1.01(1)$ at 11 (cited in note 1).

81 See $A$ LI Principles $\$ 4.03$ (d) at 263 (cited in note 1). Additionally, as conditions of permitting self-help, the Principles require that "the transferor provide[] timely notice of the breach and its intent to use automated disablement and provide[] the transferee with a reasonable opportunity to cure the breach and the transferee has not so cured." ALI Principles $\S 4.03(\mathrm{~d})(2)$ at 264 (cited in note 1). Further, the transferor must obtain a court order permitting it to use automated disablement. ALI Principles $\$ 4.03(d)(3)$ at 264 (cited in note 1).

82 See UCC $\$ 9-609$ (a) ("After default, a secured party: [] may take possession of the collateral."). See also UCC $\$ 2$ A-525(2) (providing a right of repossession to an aggrieved lessor of goods in certain circumstances); Mark P. Gergen, A Theory of Self-Help Remedies in Contract, 89 BU L Rev 1397, 1397-1401 (2009) (discussing self-help rules and how they fit with contract law theories); Celia R. Taylor, Self-Help in Contract Law: An Exploration and Proposal, 33 Wake Forest L Rev 839, 864-81 (1998) (describing the self-help doctrine under the UCC and Restatement (Second) of Contracts and proposing changes to existing law to encourage self-help in commercial transactions).

83 See note 7 and accompanying text. 
Article 9, the use of electronic self-help is a relatively recent phenomenon, and whether a licensee would expect its use in the absence of a contractual term is an open question. ${ }^{84}$ We think that the licensee often would not and, in particular, that an intent to use automated disablement alters the valuation of the contract such that, were it not disclosed, the licensee would pay too much for the software.

To disable remotely software resident on another computer requires that the software provider write its code to include a way to enter the licensee's system from outside - a so-called "back door." The mere existence of this back door places the licensee's system at risk by making it less secure. ${ }^{86}$ Further, computers generally have a number of software programs and accompanying data installed. Automated disablement can adversely affect programs and data having nothing to do with the contractual dispute between the parties. Damages from disablement can be quite high: lack of access to software and data can have far-reaching effects on the licensee and third parties with whom the licensee's system is networked or with whom it does business.

Additionally, breach of contract is often a highly contextual inquiry. Complicating matters in the area of software contracting is the overlay of federal intellectual property law that may bear on the

84 The debates over the electronic self-help provision of the Uniform Computer Information Transactions Act (UCITA) are illustrative. In its 1999 version, UCITA provided a limited right of electronic self-help, requiring the licensee's separate assent to a term in the agreement authorizing its use and postbreach notice of intent to exercise the remedy. UCITA $\$ 816$ (NCCUSL 1999). Commentators disagreed on the desirability of this provision. See sources cited in ALI Principles $\S 4.03$, comment a at 265 (cited in note 1) (noting that "the question of remote disablement by [licensors] was one of the most controversial of UCITA's remedial provisions" and arguing that the ALI Principles "represent a reasonable compromise between freedom of contract ... and the legitimate concerns of [licensees] even when they have agreed to permit electronic self-help"). Eventually UCITA prohibited electronic self-help. UCITA $\S 816(\mathrm{~b})$ (NCCUSL 2002). See also Raymond T. Nimmer, 2 Information Law $\$ 11: 156$ at 11-351 (West 2006):

The difficulty with examining electronic self-help under existing law is that the common law and the UCC rules were not developed with attention to the protective capability of digital systems or to their potential for abuse. The ability to disable the other party's use of the technology creates strong leverage to enforce performance. This benefits licensors, but leverage can mount into undesirable duress or coercion.

85 See Cem Kaner, Why You Should Oppose UCITA, 17 Computer L 20, 26 (May 2000) ("[D]isabling codes create a hole in the customer's system security.").

86 See id.

87 See Timothy P. Heaton, Note, Electronic Self-Help Software Repossession: A Proposal to Protect Small Software Development Companies, 6 BU J Sci \& Tech L 205, 212 (2000) ("Computer systems hold an immense amount of data; lack of access to that data because of a software disablement could have effects far beyond the value of the breached licensing agreement."), and sources cited therein.

88 See id at 212-13. 
enforceability of particular provisions. ${ }^{89}$ For example, a party may premise the right to automated disablement on breach of a contractual provision against reverse engineering. But patent law, copyright law, or both may render that provision unenforceable and thus the disablement (that may cause large damages) wrongful. ${ }^{90}$ Unlike repossession of tangible goods, electronic repossession of informational goods implicates difficult questions of intellectual property law, suggesting that more caution is appropriate in this context. ${ }^{9 \mathrm{P}}$

UCC Article 9's self-help repossession scheme is limited by the malleable concept of breach of the peace..$^{92}$ A repossession carried out in breach of the peace is wrongful, and the debtor is entitled to damages. ${ }^{93}$ The breach of the peace limitation makes it difficult for a foreclosing secured party to enter the debtor's dwelling or place of business to repossess collateral in the absence of the debtor's consent. ${ }^{94}$

At first glance, electronic self-help seems to eliminate any breach of the peace issue. To the extent that the breach of the peace limitation is intended to forestall the violence inherent in a face-to-face confrontation over repossession, this is indeed the case. The breach of the peace doctrine in Article 9, however, may vindicate interests in addition to preventing violence, including "protect[ing] dignitary losses to debtors[;] ... protect[ing] the sanctity of private dwellings; [and] enabl[ing] debtors, by contesting repossession, to force creditors to proceed by action." ${ }^{95}$ The expectation of privacy in the sense of freedom from nonconsensual intrusion is an evolving concept in the high-tech area, but there is some evidence that consumers, at least, are likely to react with dismay when vendors monitor their computer activities in one

89 See ALI Principles $\S 1.09$ at 44 (cited in note 1); Julie E. Cohen, Copyright and the Jurisprudence of Self-Help, 13 Berkeley Tech L J 1089, 1128-37 (1998).

90 See $A L I$ Principles $\$ 1.09$ at 44 (cited in note 1) (describing the circumstances under which an agreement may be unenforceable under federal intellectual property law).

91 See Cohen, 13 Berkeley Tech $\mathrm{L}$ J at 1136-37 (cited in note 89) ("May the states reshape their law of contract to allow automatic, self-enforcing foreclosure of conduct privileged by copyright law and, ultimately, by the Intellectual Property Clause and First Amendment ... ? [T]he answer must be no.").

92 UCC \& 9-609(b)(2) ("A secured party may [take possession of the collateral] ... without judicial process, if it proceeds without breach of the peace."). See also notes 94-95 and accompanying text.

93 UCC $\$ 9-625$. Note that an aggrieved debtor may recover damages in tort law under a trespass or conversion theory. See UCC $\$ 9-625$, comment 3 ("[P]rinciples of tort law supplement [\$9-625]. However, to the extent that damages in tort compensate the debtor for the same loss dealt with by this Article, the debtor should be entitled to only one recovery.").

94 See James J. White and Robert S. Summers, 4 Uniform Commercial Code $\$ 34-8$ at $444-47$ (West 6th ed 2010) (discussing breach of the peace doctrine).

95 Alan Schwartz and Robert E. Scott, Commercial Transactions: Principles and Policies 950 (Foundation 2d ed 1991). 
way or another. ${ }^{96}$ We think that businesses would also be surprised by an automated disablement of software in the absence of a contractual provision permitting it.

For all of these reasons, we believe that requiring disclosure of an intent to use electronic means to disable software remotely is amply justified. ${ }^{97}$ Disclosure as a condition of enforcement is not costly and will force the software licensor to bring to the licensee's attention its intent to use this unusual, intrusive remedy. The licensee can then make an informed judgment about whether to enter into the agreement and at what price.

Some parties interested in the Principles objected to our prohibiting electronic self-help in consumer agreements and in other retaillike transactions. ${ }^{93}$ In both of these contexts, we believe that disclosure in the agreement is insufficient to drive home to the licensee the possibility and ramifications of automated disablement. In part, this is because, as we have noted, consumers are unlikely to read their standard forms. ${ }^{97}$ In addition, consumers and other licensees in retail transactions likely will not appreciate and correctly value the potentially dire consequences of remote disablement. ${ }^{100}$

Others objected to our imposing burdens in addition to disclosure-notice, an opportunity to cure, and obtaining a court order before engaging in automated disablement. ${ }^{101}$ The Principles also provide for damages for violation of the restrictions on automated disablement notwithstanding an agreement to the contrary and make the obligations in the relevant section nonwaivable. ${ }^{102}$ Justifying these requirements is beyond the scope of this Article. Here we simply note that disclosure is one part of a multifaceted approach to automated disablement..$^{103}$

96 See, for example, Cohen, 13 Berkeley Tech L J at 1105-06 (cited in note 89) (noting consumer dismay over Microsoft's program that used the Internet to report back to Microsoft about the contents of users' hard drives). The ALI Principles do not allow self-help in a consumer agreement. See ALI Principles $\$ 4.03$ (c) at 263 (cited in note 1).

97 The case law generally supports this view. See Robbin Rahman, Comment, Electronic Self-Help Repossession and You: A Computer Software Vendor's Guide to Staying Out of Jail, 48 Emory L J 1477, 1499-1503 (1999) (collecting cases). See also Conn Gen Stat Ann $\$ 42 \mathrm{a}-9-609$ (d)(2) (West).

98 For the ALI Principles' definitions of these kinds of transactions, see note 80 .

99 See note 46 and accompanying text.

100 For example, licensees may be overly optimistic that nothing will go wrong or fail to appreciate the potential for automated disablement to affect adversely other programs and reduce privacy. See notes $85-88,96$, and accompanying text.

101 ALI Principles $\S 4.03$ (d)(2)-(3) at 264 (cited in note 1). See also note 81.

102 ALI Principles $\S 4.03$ (e)-(f) at 264 (cited in note 1 ).

103 For a discussion of these requirements, see $A L I$ Principles $\$ 4.03$ \& comments at $263-68$ (cited in note 1). 


\section{CONCLUSION}

Our aim here was to use certain provisions of the ALI Principles as case studies to show that disclosure can play a useful-indeed, centralrole in helping to legitimize a legal regime. Particularly where the cost of disclosure is low, it can promote values as diverse as economic efficiency, due process, and corrective justice. In the case of disclosure of material hidden defects and disclosure of an intent to use automated disablement as a remedy for breach, among other things, disclosure performs the important function of increasing the probability that the transferee of the software will value the transaction correctly. In the case of standard forms, disclosure seems the most practical of a host of imperfect solutions or, at minimum, is a necessary precursor to other solutions. By itself, disclosure of standard forms at least provides an opportunity for transferees to read the terms. This opportunity supports important values even if very few licensees actually avail themselves of it. Disclosure in the case of standard forms also raises the potential in the longer run for improving the quality of standard terms. ${ }^{104}$

104 Although the disclosure sections of the ALI Principles have proven to be the most controversial, one article complains that the Principles do not adequately cover "softwarespecific issues" and include too many generic contract law issues. See Juliet M. Moringiello and William L. Reynolds, What's Software Got to Do with It? The ALI Principles of the Law of Software Contracts, 84 Tulane L Rev 1541, 1547-49 (2010). We do not find their critique troubling or correct. For example, the Principles devote twenty-five pages to guidance on federal preemption in the black letter, comments, and Reporters' Notes, but all that Moringiello and Reynolds can muster is that more should have been done in the "black letter." Id at 1546. Further, we firmly believe that the Principles should cover issues that also arise in other contract settings but may have special significance in the software arena. For example, covering contract interpretation is important because, as the Principles state, rapid changes in technology mean that software terms often do not keep up with the parties' understandings of the nature of the software being transferred or of its authorized uses. See ALI Principles at 215 (cited in note 1). 